\title{
Piping network design of geothermal district heating systems: Case study for a university campus
}

\author{
Nurdan Yildirim, Macit Toksoy, Gulden Gokcen* \\ Mechanical Engineering Department, Izmir Institute of Technology, 35430 Gulbahce Koyu, Urla-Izmir, Turkey
}

\section{A R T I C L E I N F O}

\section{Article history:}

Received 2 October 2009

Received in revised form

5 April 2010

Accepted 7 April 2010

Available online 15 May 2010

\section{Keywords:}

Geothermal

District heating systems

Piping network design

Heat pump

\begin{abstract}
A B S T R A C T
Geothermal district heating system design consists of two parts: heating system and piping network design. District heating system design and a case study for a university campus is given in Yildirim et al. [1] in detail. In this study, piping network design optimisation is evaluated based on heat centre location depending upon the cost and common design parameters of piping networks which are pipe materials, target pressure loss (TPL) per unit length of pipes and installation type. Then a case study for the same campus is presented.
\end{abstract}

(c) 2010 Elsevier Ltd. All rights reserved.

\section{Introduction}

Geothermal district heating, and in some cases district cooling networks are designed to provide space heating and/or cooling to multiple consumers from a single or multiple production wells or fields. The development of geothermal district heating systems has been one of the fastest growing segments of the geothermal direct use applications and accounts for over $80 \%$ of all space heating provided from geothermal resources worldwide [2,3].

Because of the majority of its geothermal resources is medium to low temperature, direct use applications and consequently district heating systems are widely used in Turkey. Considering 20 district heating systems with a total installed capacity of approximately $400 \mathrm{MW}_{\mathrm{t}}$, Turkey is one of the leading countries on geothermal direct use applications in the World [2-4].

The studies on geothermal district heating systems are mostly focused on energy and exergy analysis of the existing systems [5-13], thermal effects of control logics [12,14], economic assessment of the systems [15-20], development of models and corresponding computer codes to simulate district heating systems including piping network $[12,18,21-26]$ and heating system design neglecting the piping network [27].

Piping networks have a significant share as high as $60 \%$ of the total investment cost of geothermal district heating systems [28].

\footnotetext{
* Corresponding author. Tel.: +90 232 7506706; fax: +90 2327506701 .

E-mail address: guldengokcen@iyte.edu.tr (G. Gokcen).
}

Therefore, optimisation of the district heating piping network is of vital importance to the economics of whole system.

This study differs from the previous ones in that piping network design is optimised depending upon the cost and common design parameters of piping networks which are heat centre location, target pressure loss (TPL) per unit length of the pipe, pipe materials and installation type.

Izmir Institute of Technology (IZTECH) campus is under construction since the year of 2000 . The number of the buildings has currently reached to 15 with a floor area of $50,730 \mathrm{~m}^{2}$. The total heat load of the existing buildings is about $3662 \mathrm{~kW}$. Once the development is completed, total heat load of the campus will reach to $11,207 \mathrm{~kW}$.

Individual heating, ventilation and air conditioning systems (HVAC) are employed at each building group. On the other hand, there exists a geothermal resource in the vicinity of the campus where exploration studies were conducted between 1995 and 2002. Five gradient wells were drilled, one of which located on the coast of Gulbahce Bay, was assigned as production well having a temperature of $33{ }^{\circ} \mathrm{C}$ and a flowrate of $30 \mathrm{~kg} / \mathrm{s}$, and considered to be used for campus heating and cooling. Because of the low temperature geothermal resource, heat pump district heating system (HPDHS) was studied and compared with existing individual fuel boiler heating system (IFBHS) and fuel boiler district heating system (FBDHS) for the campus. Each system was simulated hourly with a control parameter of indoor air temperature. Various heating regime alternatives were studied for various 


\begin{tabular}{|ll|}
\hline Nomenclature \\
$\dot{m}$ & fluid flowrate $(\mathrm{kg} / \mathrm{s})$ \\
Cost $_{\text {cir }}$ & annual operational pumping cost $(\mathrm{US} \$)$ \\
$g$ & gravitational acceleration constant $\left(9.81 \mathrm{~m} / \mathrm{s}^{2}\right)$ \\
$h_{\mathrm{p}}$ & total dynamic head of pump $(\mathrm{m})$ \\
$P_{\mathrm{el}}$ & unit cost of electricity (US $\$ \mathrm{kWh})$ \\
$\eta_{\text {motor }}$ & motor efficiency $(-)$ \\
$\eta_{\text {pump }}$ & pump efficiency $(-)$ \\
\hline
\end{tabular}

condenser outlet temperatures and geothermal fluid flowrates. Finally economic analysis indicated that HPDHS was more attractive than IFBHS and FBDHS [29]. Heating system design for the campus was given in Yildirim et al. [1] in detail.

In this study, piping network design optimisation of the campus HPDHS is evaluated based on heat centre location depending upon the cost and common design parameters of piping networks which are pipe materials, TPL per unit length of the pipe and installation type. PipeLab software [25] is used as simulation tool.

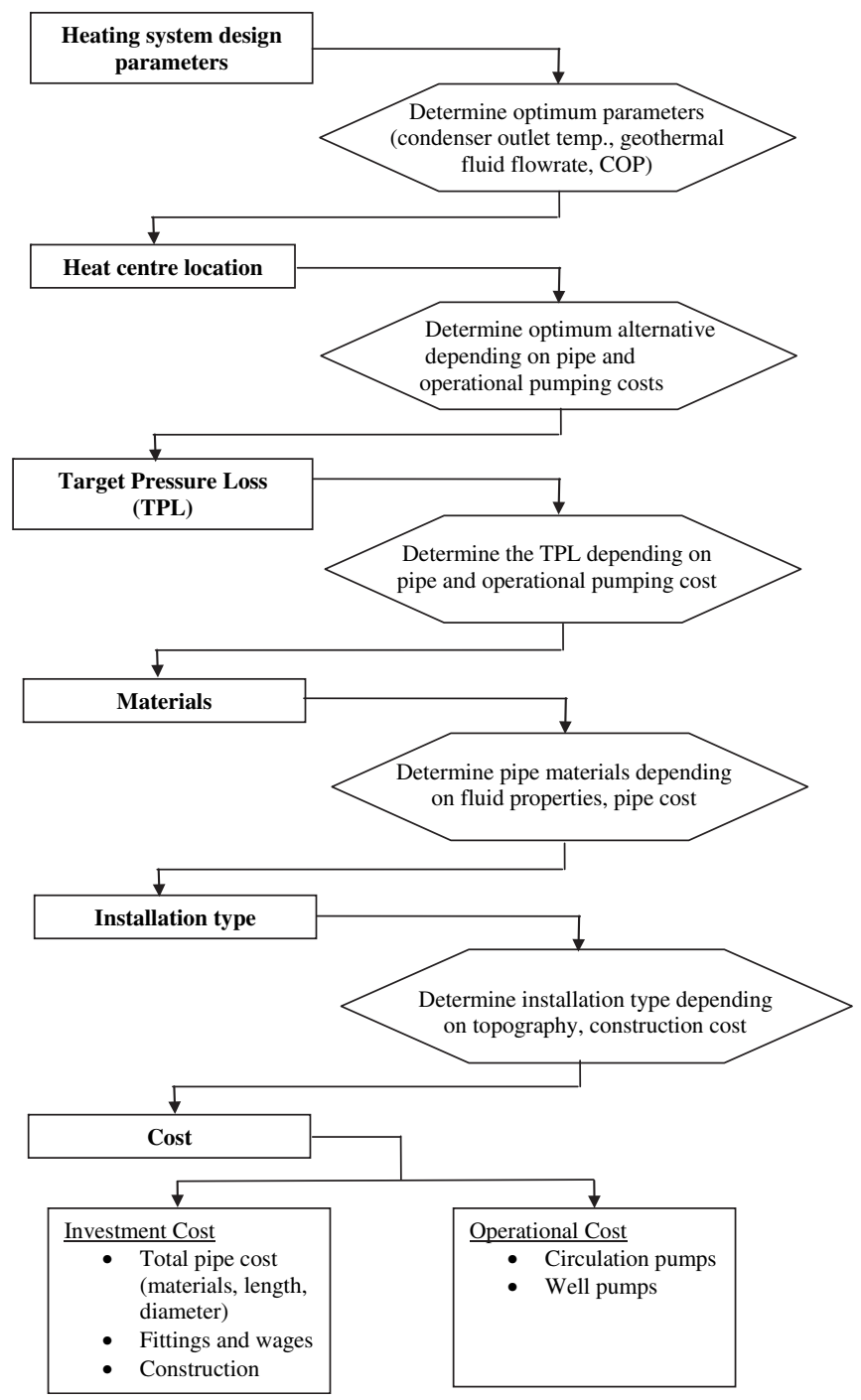

Fig. 1. Flow diagram of piping network design.

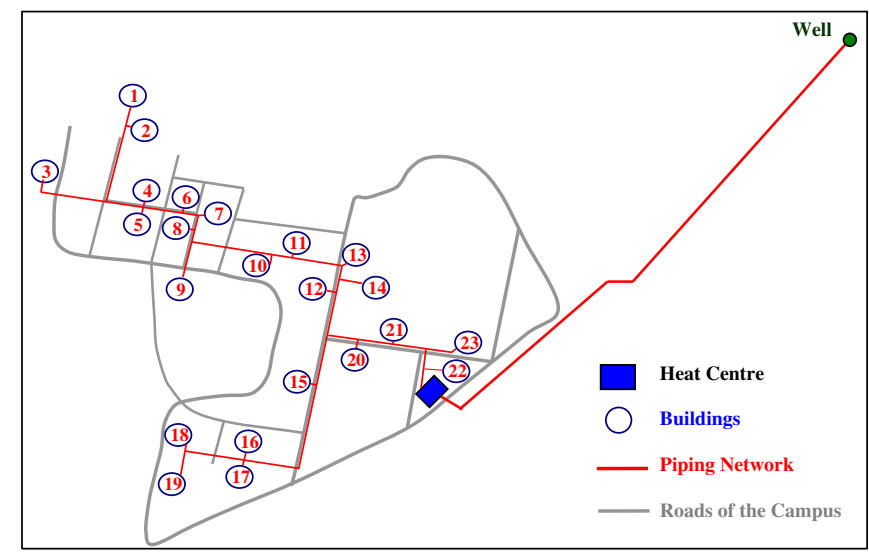

Fig. 2. District heating piping network: Alternative 1.

\section{Piping network design}

Design parameters of piping network include heat centre location, TPL, piping materials, installation type and the outcome of heating system design parameters such as condenser outlet temperature and geothermal fluid flowrate [1].

The location of the heat centre is critical because it determines pressure loss, pipe length and consequently cost of the whole district heating system.

TPL is a common design parameter of piping networks. District heating practice is to design the system for $50-200 \mathrm{~Pa} / \mathrm{m}$ pressure loss [24]. If the pressure loss is high, investment cost of the pipes decreases, while operational cost increases. On the other hand, when the pressure loss is low, the investment cost increases because of larger pipe diameters, but operational cost decreases.

Optimum pipe diameters are calculated based on TPL, water velocity, head loss in the network and cost. Since piping network has an important share on the total investment cost, optimisation of the pipe diameters is quite important for the economical viability of the whole system. Pipe diameter selection also has a crucial impact on operational cost. Total piping cost consists of pipe cost, fittings and wages, and construction costs while operational pumping cost includes pumping cost of campus and geothermal loops circulation pumps and well pumps.

Piping materials for geothermal district heating systems have been of numerous types with great variation in cost and durability. The temperature and chemical quality of geothermal fluids, in

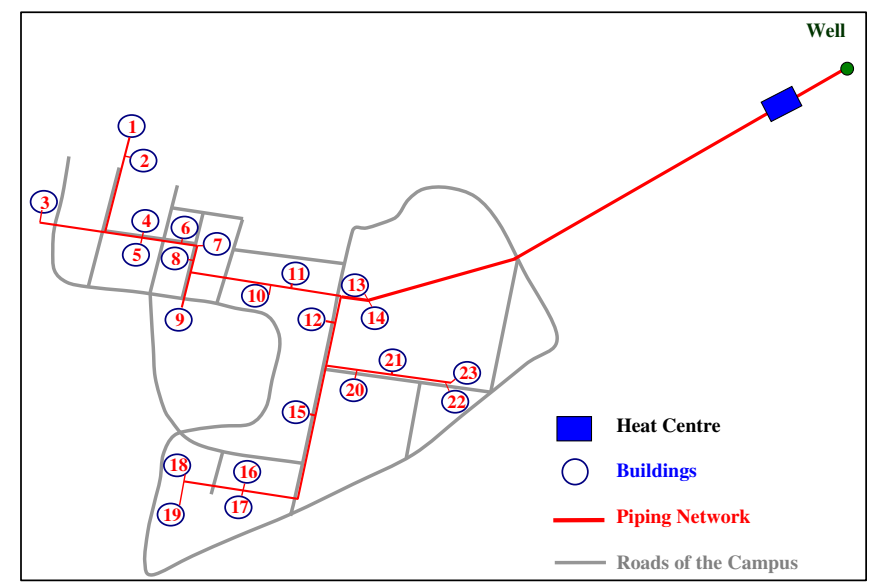

Fig. 3. District heating piping network: Alternative 2 . 


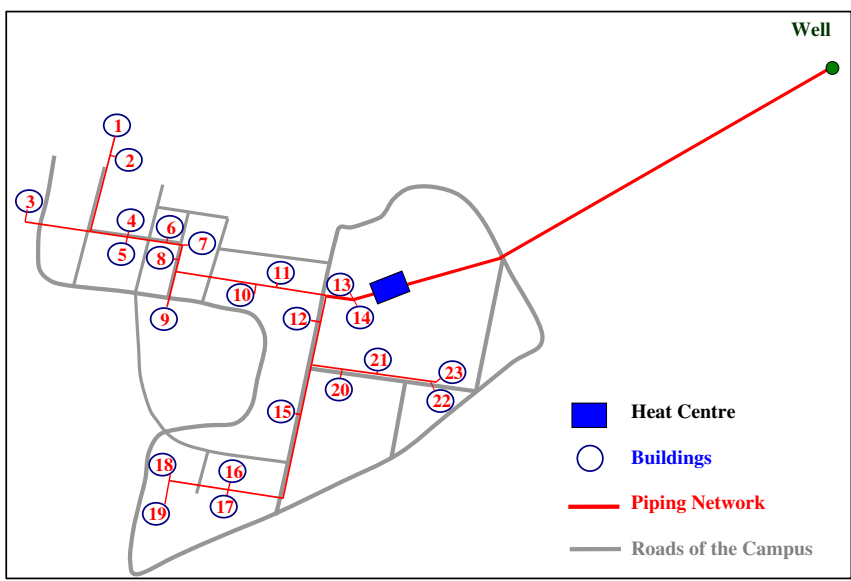

Fig. 4. District heating piping network: Alternative 3.

addition to cost, usually determine the type of piping network materials used. Carbon steel is currently the most widely used material for geothermal transmission lines and distribution networks, especially if the fluid temperature is over $100{ }^{\circ} \mathrm{C}$. On the other hand, composite (FRP) pipes are used because of the corrosive effects of the geothermal fluid [30-32].

Use of pre-insulated pipes in geothermal district heating applications is common and it minimizes heat losses during the transmission of the fluid. Pre-insulated pipes consist of a carrier pipe, through which the fluid is transported, an insulation layer, and a jacket material. Transmission of a $115{ }^{\circ} \mathrm{C}$ fluid over $3 \mathrm{~km}$ distance in $1 \mathrm{~m}$ diameter pipes is calculated to cause only about a $1{ }^{\circ} \mathrm{C}$ drop in temperature when pre-insulated pipes are used $[19,33]$. Therefore, heat losses during the transmission of the fluid can be neglected.

Pipelines are installed either aboveground or underground. Aboveground installations typically are supported on concrete pipe supports and rollers. This installation eliminates conflicts with buried utilities and may be easier to maintain. However, aboveground installations are more subject to damage and vandalism. Pipe supports and constraints, road crossings, venting, expansion provisions and insulation protection are important considerations in the aboveground design. Buried piping systems, the most common type of distribution network are aesthetically more pleasing and safe for accidental or intentional damage than aboveground installations.
Table 1

Pressure drops, pipe lengths, total pipe and operational pumping costs of heat centre location alternatives (design temperatures: $45 / 35^{\circ} \mathrm{C}$, TPL: $62.5 \mathrm{~Pa} / \mathrm{m}$ ).

\begin{tabular}{|c|c|c|c|c|}
\hline & & Alternative 1 & Alternative 2 & Alternative 3 \\
\hline Total pressure dro & $\mathrm{p}(\mathrm{m})$ & 14.8 & 17.1 & 11.2 \\
\hline Campus loop pipe & DN80 & 41.36 & 41.36 & 41.36 \\
\hline length $(\mathrm{m})$ & DN100 & 639.28 & 632.17 & 632.17 \\
\hline & DN125 & 494.64 & 494.97 & 494.97 \\
\hline & DN150 & 304.58 & 423.68 & 423.68 \\
\hline & DN200 & 728.56 & 894.28 & 894.28 \\
\hline & DN250 & 537.62 & 534.88 & 534.88 \\
\hline & DN300 & 175.86 & 374.47 & 374.47 \\
\hline & DN350 & 193.94 & 0 & 0 \\
\hline & DN400 & 324.26 & 70.44 & 70.44 \\
\hline & DN450 & 39.27 & 1120 & 52.92 \\
\hline & Total & 3479.37 & 4586.25 & 3519.17 \\
\hline Geothermal loop & DN300 & & & 1223 \\
\hline pipe length (m) & DN350 & 1513 & & \\
\hline & DN400 & & 53.3 & \\
\hline Pipe cost (US\$) & Campus loop & $182,862.7$ & $335,725.4$ & $159,657.2$ \\
\hline & $\begin{array}{l}\text { Geothermal } \\
\text { loop }\end{array}$ & $174,024.3$ & 8265.07 & $106,401.3$ \\
\hline & $\begin{array}{l}\text { Total (supply + } \\
\text { return) }\end{array}$ & 713,774 & 687,981 & 532,117 \\
\hline $\begin{array}{l}\text { Operational } \\
\text { pumping } \\
\text { cost (US\$) }\end{array}$ & & 23,446 & 27,089 & 17,743 \\
\hline
\end{tabular}

For underground installation there are two options, which are directly buried into the soil and in concrete tunnel. Concrete tunnels have the advantages, providing access for maintenance, easing future expansion and a corridor for other utilities such as domestic water, electrical cables, phone lines, etc. But because of the high investment cost of the concrete tunnel, generally directly buried into the soil installation type is preferred [2,3,33].

\section{Methods}

The flow diagram of piping network design is shown in Fig. 1. Heating system design parameters are obtained from Yildirim et al. [1].

District heating network is designed considering not only existing buildings but also future development.

\subsection{Heat centre location}

Several alternatives for heat centre location have been studied and three of which are given in this study.

Table 2

Pipe diameters, pipe and operational pumping costs for various TPLs (Alternative 3, TPL: $150 \mathrm{~Pa} / \mathrm{m}$ ).

\begin{tabular}{|c|c|c|c|c|c|c|c|}
\hline & & \multicolumn{6}{|l|}{$\mathrm{TPL}(\mathrm{Pa} / \mathrm{m})$} \\
\hline & & \multicolumn{2}{|l|}{62.5} & \multicolumn{2}{|l|}{100} & \multicolumn{2}{|l|}{150} \\
\hline & & Campus loop & Geothermal loop & Campus loop & Geothermal loop & Campus loop & Geothermal loop \\
\hline \multirow[t]{11}{*}{ Pipe length (m) } & DN65 & & & 41 & & 41 & \\
\hline & DN80 & 41 & & 429 & & 489 & \\
\hline & DN100 & 632 & & 362 & & 638 & \\
\hline & DN125 & 495 & & 521 & & 205 & \\
\hline & DN150 & 424 & & 726 & & 1000 & \\
\hline & DN200 & 894 & & 443 & & 565 & \\
\hline & DN250 & 535 & & 821 & & 457 & 1223 \\
\hline & DN300 & 374 & 1223 & 53 & 1223 & 0 & \\
\hline & DN350 & 0 & & 70 & & 123 & \\
\hline & DN400 & 70 & & 53 & & & \\
\hline & DN450 & 53 & & & & & \\
\hline \multirow[t]{2}{*}{ Pipe cost (US\$) } & Supply loop & 159,657 & 106,402 & 136,963 & 106,402 & 124,495 & 92,948 \\
\hline & Total (supply + return) & 532,117 & & 486,730 & & 434,887 & \\
\hline \multicolumn{2}{|c|}{ Operational pumping cost (US\$) } & 17,743 & & 20,125 & & 21,966 & \\
\hline
\end{tabular}




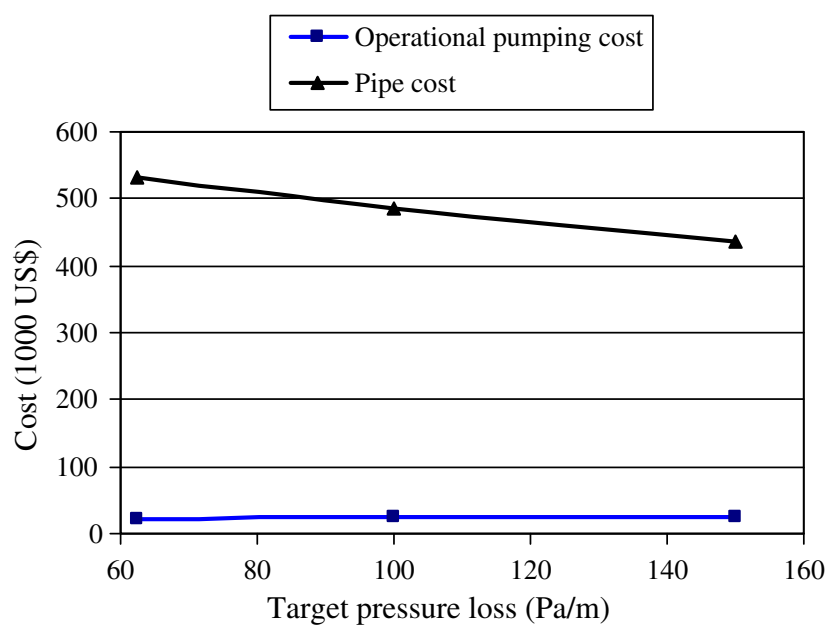

Fig. 5. Operational pumping and pipe cost for the network.

Each alternative is simulated by PipeLab software [25] which uses graph theory to solve flow and heat distribution problems of piping networks at design phase and to analyse the existing networks. The required input file for PipeLab includes number of nodes in the system, their $x y z$ coordinates, connectivity relation to the nodes of the pipes with their length, diameter and roughness, boundary conditions, required flowrate and the pressure head at the starting point. Initially, pipe diameters are assumed and then optimum diameter for each pipe is calculated by PipeLab. Pressure drop of the critical line and pipe diameters are calculated for the campus loop design temperatures and default TPL of PipeLab. Depending on the lowest pipe and operational pumping costs and pressure drop, one of the alternatives is chosen as the best option.

\subsection{Target pressure loss}

For the best heat centre location option, various TPLs are tested for pipe diameter selection in PipeLab. District heating practice is to design the system for $50-200 \mathrm{~Pa} / \mathrm{m}$ pressure loss [24]. Pipe diameter selection depends on pipe and operational pumping costs. Operational pumping cost is calculated by Eq. (1).

Cost $_{\mathrm{cir}}=\frac{\dot{m} \cdot g \cdot h_{\mathrm{p}}}{1000 \cdot \eta_{\mathrm{motor}} \cdot \eta_{\mathrm{pump}}} \cdot P_{\mathrm{el}}$

$h_{\mathrm{p}}$ can be calculated from heating system pressure drop by PipeLab depending on the flowrate.

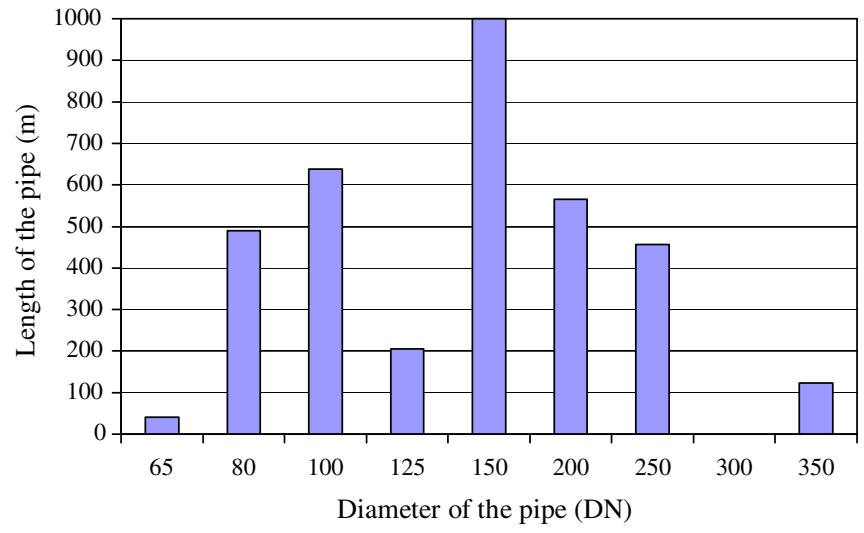

Fig. 6. Length of each pipe diameter used in the supply main of the campus loop.

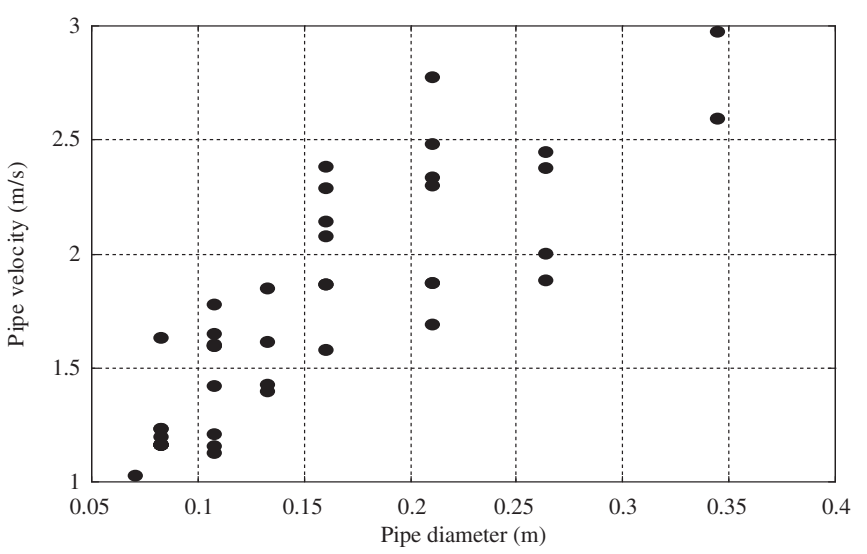

Fig. 7. Relationship between pipe diameter and velocity of water.

\subsection{Materials selection}

Common pipe materials used in geothermal district heating applications in Turkey are carbon steel and composites. These two pipe materials are compared depending on fluid properties, temperature and piping cost.

\subsection{Pipeline installation}

Considering its advantages, buried piping system is preferred in this study and, directly buried and concrete tunnel installations are compared regarding with cost. Unit construction cost for buried and concrete tunnel installations is $33.4 \mathrm{US} \$ / \mathrm{m}$ and $200 \mathrm{US} \$ / \mathrm{m}$, respectively [34].

Cost of fittings and wages for the workers are assumed to be $30 \%$ of total cost of the piping network.

\section{Results}

\subsection{Heating system design parameters}

At the given geothermal fluid temperature $\left(T_{\mathrm{gi}}\right)$ of $33{ }^{\circ} \mathrm{C}$ and condenser inlet temperature of $35{ }^{\circ} \mathrm{C}$, coefficients of performance (COP) of heat pump system for various condenser outlet temperatures $\left(40-55^{\circ} \mathrm{C}\right)$ were plotted depending upon geothermal fluid flowrate. Regarding with manufacturer's catalogues and the target of minimizing the temperature difference between condenser inlet and outlet; COP, heating system design parameters of condenser

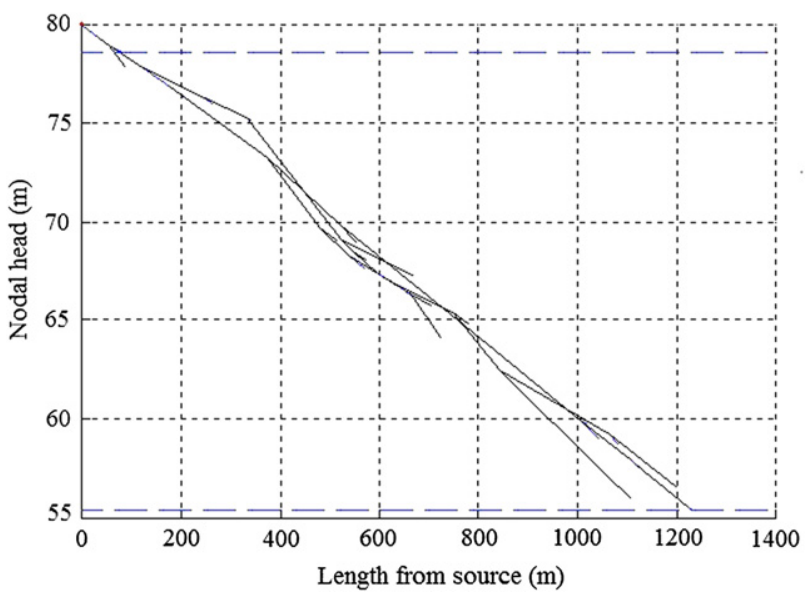

Fig. 8. $h / L$ diagram for the campus loop supply main. 


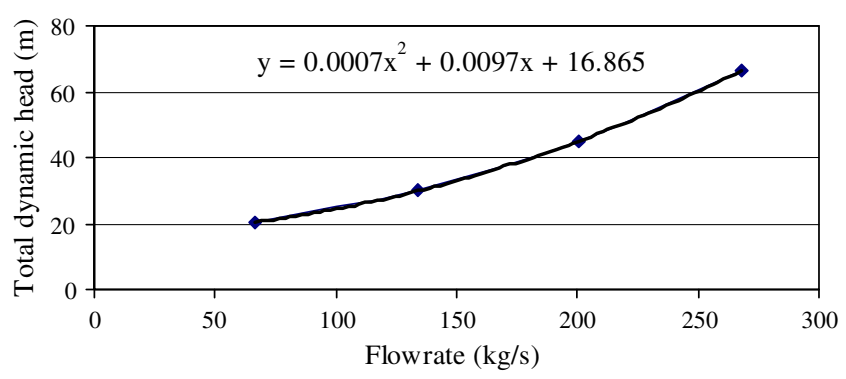

Fig. 9. Variation of total dynamic head of the campus loop circulation pump versus secondary water flowrate.

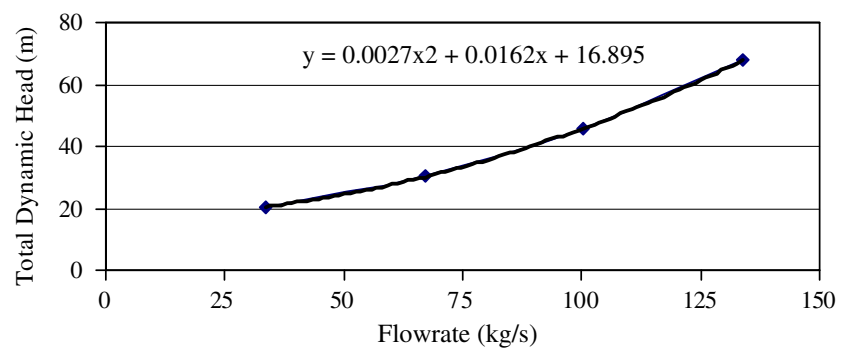

Fig. 10. Variation of total dynamic head of the geothermal loop circulation pump depending on the geothermal fluid flowrate.

outlet temperature and geothermal fluid flowrate were determined as $6,45^{\circ} \mathrm{C}$ and $120 \mathrm{~kg} / \mathrm{s}$, respectively [1].

\subsection{Heat centre location}

Three alternatives of heat centre location are:

- Alternative 1: Heat centre is close to the campus main entrance (Fig. 2).

- Alternative 2: Heat centre is close to the production well (Fig. 3).

- Alternative 3: Heat centre is in the middle of the campus (Fig. 4).

Pressure drop of the critical line, pipe lengths in various diameters, pipe and operational pumping costs were calculated for the campus loop design temperatures $\left(45^{\circ} \mathrm{C}\right.$ condenser outlet/ $35{ }^{\circ} \mathrm{C}$ condenser inlet) [1] and $62.5 \mathrm{~Pa} / \mathrm{m}$ TPL, which is default TPL of PipeLab for each alternative and the results are given in Table 1. Alternative 2 has the highest pressure drop and requires the longest pipeline. Although Alternative 1 and 3 are close to each other in pipe length, Alternative 3 requires shorter pipe length at larger pipe diameters which makes it more cost effective. Resulting the lowest pipe and operational pumping costs and pressure drop, Alternative 3 seems to be the best option.

\subsection{Target pressure loss}

District heating practice is to design the system for 50-200 Pa/m pressure loss [24]. Three different TPLs, which are
Table 3

Annual electricity consumption of the pumps (Alternative 3, TPL: $150 \mathrm{~Pa} / \mathrm{m}$ ).

\begin{tabular}{lcr}
\hline Pumps & $\begin{array}{l}\text { Annual electricity } \\
\text { consumption }(\mathrm{kWh})\end{array}$ & Cost (US\$) \\
& 106,270 & 9564 \\
\hline Campus loop circulation pumps & 38,739 & 3487 \\
Geothermal loop circulation pumps & 99,056 & 8915 \\
Well pumps $\left(h_{\mathrm{p}}=100 \mathrm{~m}\right)$ & 244,065 & 21,966 \\
Total & & \\
\hline
\end{tabular}

62.5, 100 and $150 \mathrm{~Pa} / \mathrm{m}$ are tested for diameter selection in PipeLab for the best option which is Alternative 3 . The results are tabulated in Table 2 and $150 \mathrm{~Pa} / \mathrm{m}$ TPL gives the lowest pipe cost since it requires shorter pipe length at larger pipe diameters.

Operational pumping and pipe costs which are calculated using Eq. (1) and unit pipe cost of each pipe diameter [35] for various TPLs are exhibited in Fig. 5. Figure indicates that while operational pumping cost is nearly constant, pipe cost decreases drastically with increasing TPL. Therefore, the highest acceptable TPL, $150 \mathrm{~Pa} / \mathrm{m}$, can be selected for the design of district heating piping network [29].

After determining the TPL for Alternative 3, the length of each pipe diameter for geothermal and campus loops is calculated. Pipe diameters vary between DN 65-350 for the campus loop (Table 2 and Fig. 6) and DN 250 for the geothermal loop. Number of the nodes in the supply main is 46 and total pipe length is $3518 \mathrm{~m}$. Return main is assumed to have the same pipe diameter and length with the supply main. The relationship between the pipe diameter and the water velocity is displayed in Fig. 7. Velocity range calculated as $1.03-2.98 \mathrm{~m} / \mathrm{s}$ which is in a good agreement with the literature where acceptable velocity range for water is given as $1-3 \mathrm{~m} / \mathrm{s}$ [36]. The results are also the same for the campus return main.

PipeLab exhibits the head loss distribution on the network. The $h / L$ diagram of the supply main of the campus loop is shown in Fig. 8. Pressure drop is calculated as $24.6 \mathrm{~m}$ for the supply and return mains. Heat centre pressure drop is assumed as $25 \mathrm{~m}$. Thus, pressure head for the system is $80 \mathrm{~m}$.

The occupancy schedule of the campus is 9.00 a.m. -17.00 p.m. during the week. Thus, the operational cost of the pumps is calculated for this period by Eq. (1). Fig. 9 displays the variation of the total dynamic head of the campus loop water circulation pumps versus campus loop flowrate. The equation, derived from Fig. 9, is used to calculate the annual electricity consumption of the campus loop circulation pumps for a 95\% motor and $75 \%$ pump efficiencies. Annual electricity consumption of the geothermal loop circulation pumps is determined in the same way. Variation of the total dynamic head of the geothermal loop circulation pump versus geothermal fluid flowrate and annual electricity consumption is shown in Fig. 10 and Table 3, respectively.

\subsection{Materials selection}

Unit cost of carbon steel and composite pipes are given in Table 4 [35] which indicates that, carbon steel pipes are approximately $13-35 \%$ cheaper than composite pipes depending on the pipe diameter. On the other hand, because of the corrosive effects of

Table 4

Unit cost of carbon steel and composite pipes (Alternative 3) [35].

\begin{tabular}{|c|c|c|c|c|c|c|c|c|c|c|c|c|}
\hline & Diameter (DN) & 65 & 80 & 100 & 125 & 150 & 200 & 250 & 300 & 350 & 400 & 450 \\
\hline \multirow[t]{2}{*}{ Unit pipe cost (US\$/m) } & Carbon steel pipe (steel $+\mathrm{PU}+\mathrm{PE})$ & 13 & 15 & 25 & 26 & 31 & 47 & 57 & 72 & 95 & 128 & 165 \\
\hline & Composite pipe (CTP + PU + CTP) & 20 & 23 & 31 & 32 & 42 & 54 & 76 & 87 & 115 & 155 & 199 \\
\hline
\end{tabular}


Table 5

Main results of piping network design for the supply mains (Alternative 3, TPL $150 \mathrm{~Pa} / \mathrm{m})$.

\begin{tabular}{|c|c|c|c|c|}
\hline $\begin{array}{l}\text { Part of the piping } \\
\text { network }\end{array}$ & $\begin{array}{l}\text { Total pipe } \\
\text { length }(\mathrm{m})\end{array}$ & Pipe material & $\begin{array}{l}\text { Pipe cost } \\
\text { (US\$) }\end{array}$ & $\begin{array}{l}\text { Pressure } \\
\text { drop (m) }\end{array}$ \\
\hline Campus loop & 3520 & Carbon steel & 248,991 & 24.6 \\
\hline Geothermal loop & 1223 & Composite & 185,896 & 25.3 \\
\hline
\end{tabular}

the geothermal fluid, composite (FRP) pipes are preferred for geothermal loop while campus loop is installed using carbon steel pipes.

Main results of piping network design for supply mains of HPDHS are given in Table 5 . As can be seen from the table, total length of the pipes in the supply main of the campus and geothermal loops are $3520 \mathrm{~m}$ and $1223 \mathrm{~m}$, respectively. Thus, total length of considered network of the district heating system is approximately $9486 \mathrm{~m}$. Total pipe cost of the campus and geothermal loops account as 248,991 US\$ and 185,896 US\$, respectively (for $150 \mathrm{~Pa} / \mathrm{m}$ TPL). Thus, the total pipe cost of the district heating system amounts approximately to 434,887 US\$.

\subsection{Pipeline installation}

Total piping cost for underground installation including construction, fittings and wages is listed and compared in Table 6. Table clearly indicates that piping cost is 2.3 times more expensive for concrete tunnel than directly buried installation. Therefore, for IZTECH campus HPDHS directly buried pipeline installation is selected and all pipes are insulated [29].

\subsection{Economical comparison}

Total investment and operational costs of HPDHS (heating system + piping network) and existing IFBHS for IZTECH campus is given in Table 7. Table 7 indicates that investment cost of HPDHS is approximately nine times higher than IFBHS since IFBHS includes only investment cost of boilers, circulation pumps and heating equipment for new buildings excluding existing ones. On the other hand, total operational cost of HPDHS is four times lower than IFBHS. Operational cost items of HPDHS and IFBHS are electricity, fuel-oil, personnel, water, inhibitor, other chemicals and maintenance. The alternatives are evaluated according to internal rate of return (IRR) method, which shows the profit of the investment. For the IRR calculations, differences between investment, operational and amortization cost of the alternatives are used. The amortization life is considered as 20 years. In IRR calculation, annual operational costs of the systems are assumed constant during the 20 years and difference between the operational costs is considered as profit. Cash flow is the difference between annual profit and amortization cost of the systems. HPDHS and IFBHS are compared for amortization cost and the cash flow at the end of 20 years. The cash flow of HPDHS is $1,333,846$ US $\$$ depending on IFBHS and IRR is calculated as $4.07 \%$ [29].

Table 6

Total piping cost for HPDHS for underground installation (Alternative 3, TPL: $150 \mathrm{~Pa} / \mathrm{m}$ ).

\begin{tabular}{llr}
\hline Cost components & \multicolumn{2}{l}{ Cost (US\$) } \\
\cline { 2 - 3 } & Buried & Concrete tunnel \\
\hline Pipe cost & 434,887 & 434,887 \\
Fittings and wages & 130,466 & 130,466 \\
Construction & 158,132 & 948,600 \\
Total & 723,485 & $1,672,085$ \\
\hline
\end{tabular}

Table 7

Total investment and operational costs of HPDHS and IFBHS.

\begin{tabular}{llrl}
\hline Cost Components & & \multicolumn{1}{c}{ HPDHS } & \multicolumn{1}{c}{ IFBHS } \\
\hline Investment cost (US\$) & Piping network & 723,425 & 324,308 \\
& Heating system & $2,316,700$ & \\
& Total & $3,040,125$ & 324,308 \\
& Piping network & 21,966 & 466,117 \\
Operational cost (US\$) & Heating system & 105,877 & \\
& Total & 127,843 & 466,117 \\
\hline
\end{tabular}

Table 8

Investment and operational pumping cost summary (Alternative 3, TPL: $150 \mathrm{~Pa} / \mathrm{m}$ ).

\begin{tabular}{llrrr}
\hline & & $\begin{array}{l}\text { Geothermal } \\
\text { loop }\end{array}$ & \multicolumn{1}{l}{$\begin{array}{l}\text { Campus } \\
\text { loop }\end{array}$} & Total \\
& & 185,896 & 248,991 & 723,485 \\
\hline Investment cost (US\$) & Pipe & 55,769 & 74,697 & \\
& Fittings and wages & 117,357 & 40,775 & \\
& Construction & 359,022 & 364,463 & \\
Total & & 3487 & 9564 & 21,966 \\
Operational pumping & Circulation pumps & 8915 & - & \\
$\quad$ cost (US\$) & Well pumps & 12,402 & 9564 & \\
Total & & & &
\end{tabular}

\section{Conclusions}

Geothermal district heating system design includes both heating system and piping network design. Since piping network has a significant share on the total investment and operational cost, optimisation of the piping network is important for cost implications.

In this study, piping network of IZTECH campus HPDHS is simulated by PipeLab software and common piping network design parameters which are heat centre location, TPL, pipe materials and installation types, are studied to minimize the total investment and operational cost.

Heat centre location is critical because of the pressure loss, pipe length and consequently cost of the whole district heating system. Three alternatives for heat centre location are introduced in this study: one is close to the production well (Alternative 2), the others are close to the buildings (Alternative 1 and 3 ). Alternatives compared with respect to pipe length and, total pipe and operational costs. While Alternative 3 has almost the same pipe length, pipe cost encountered as $34 \%$ lower than Alternative 1 . On the other hand, Alternative 2 requires 29\% higher pipe length and 30\% higher pipe cost than Alternative 3 . The reason of the higher cost for the same pipe length is shorter pipe length at larger pipe diameters resulting higher unit cost. To minimize the total investment and operational cost of piping network, heat centre should be located close to the buildings where the building density consequently thermal load density is high.

Pipe material is selected depending on the chemical properties and temperature of the transported fluid and pipe cost. In the campus loop which carries clean water, carbon steel pipes are used while the geothermal loop accommodates composite pipes. Although total pipe length of the campus loop is approximately 3 times longer than the geothermal loop, the pipe cost is only 1.34 times higher, because of the lower cost of carbon steel pipes. Investment and operational cost items of Alternative 3 are summarised in Table 8. Although pipe cost is higher for the campus loop, when construction and, fittings and wages costs are included, total investment cost becomes equal. But operational cost for the geothermal loop is approximately $30 \%$ higher than the campus loop because of the well pumps. Considering the previous study by Yildirim et al. [1], piping network constitutes approximately $28.5 \%$ 
of the total investment and $10.2 \%$ of the total operational cost of HPDHS of IZTECH campus.

Even though buried piping installation is preferred in this study from economical point of view, concrete tunnel infrastructure may already exist or can be preferred for easy access to the other utilities. In either case, investment cost becomes more attractive.

Economical comparison between HPDHS and existing IFBHS of the campus indicated that although IFBHS does not take into account investment cost of boilers, circulation pumps and heating equipment of existing buildings, HPDHS is more attractive with a $4.07 \%$ profit at the end of the 20 -year period. HPDHS even becomes more attractive if cooling requirements of the buildings are considered [29].

Since geothermal resources are site-specific, each district heating system including heating system and piping network design should be carefully optimised depending on studied parameters in this study.

\section{References}

[1] Yildirim N, Toksoy M, Gokcen G. District heating system design for a university campus. Energy and Buildings 2006;38:1111-9.

[2] Bloomquist RG. Geothermal space heating. Geothermics 2003;32:513-26.

[3] Lund JW, Freeston DH, Boyd TL. Direct application of geothermal energy. Geothermics 2005;34:691-727.

[4] Serpen U, Aksoy N, Öngür T, Korkmaz ED. Geothermal energy in Turkey: 2008 update. Geothermics 2009;38:227-37.

[5] Chuanshan D. Thermal analysis of indirect geothermal district heating systems. Geothermics 1997;26:351-64.

[6] Ozgener L, Hepbasli A, Dincer I. Exergy analysis of two geothermal district heating systems for building applications. Energy Conversion and Management 2007;48:1185-92.

[7] Oktay Z, Aslan A. Geothermal district heating in Turkey: the Gonen case study. Geothermics 2007;36:167-82.

[8] Oktay Z, Coskun C, Dincer I. Energetic and exergetic performance investigation of the Bigadic geothermal district heating system in Turkey. Energy and Buildings 2008;40:702-9.

[9] Oktay Z, Dincer I. Energetic, exergetic and environmental assessments of the Edremit geothermal district heating system. In: ASHRAE transactions, vol. 114. NY: ASHRAE; 2008. p.116-127.

[10] Oktay Z, Dincer I. Exergoeconomic analysis of the Gonen geothermal district heating system for buildings. Energy and Buildings 2009;41:154-63.

[11] Kalinci Y, Hepbasli A, Tavman I. Determination of optimum pipe diameter along with energetic and exergetic evaluation of geothermal district heating systems: modeling and application. Energy and Buildings 2008;40:742-55.

[12] Ajah AN, Mesbah A, Grievink J, Herder PM, Falcao PW, Wennekes S. On the robustness, effectiveness and reliability of chemical and mechanical heat pumps for low-temperature heat source district heating: a comparative simulation-based analysis and evaluation. Energy 2008;33:908-29.

[13] Favrata D, Marechala F, Epellyb O. The challenge of introducing an exergy indicator in a local law on energy. Energy 2008;33:130-6.
[14] Kucuka S. The thermal effects of some control logics used in GDHS. Applied Thermal Engineering 2007;27:1495-500.

[15] Persson C, Fröling M, Svanström M. Life cycle assessment of the district heat distribution system. Part 3: use phase and overall discussion. The International Journal of Life Cycle Assessment 2006;11:437-46.

[16] Erdogmus B, Toksoy M, Ozerdem B, Aksoy N. Economic assessment of geothermal district heating systems: a case study of Balcova-Narlidere, Turkey. Energy and Buildings 2006;38:1053-9.

17] Povarov OA, Dubnov OM, Nikol'skii AI. The use of geothermal energy: a reliable, cheap and environmentally friendly method for generating electricity and heat. Thermal Engineering 2007;54:602-6.

[18] Casisi M, Pinamonti P, Reini M. Optimal lay-out and operation of combined heat \& power (CHP) distributed generation systems. Energy 2009;34: 2175-83.

[19] Kanoglu M, Cengel YA. Economic evaluation of geothermal power generation, heating, and cooling. Energy 1999;24:501-9.

[20] Molyneaux A, Leyland G, Favrat D. Environomic multi-objective optimisation of a district heating network considering centralized and decentralized heat pumps. Energy 2010;35:751-8.

[21] Stevanovic VD, Prica S, Maslovaric B, Zivkovic B, Nikodijevic S. Efficient numerical method for district heating system hydraulics. Energy Conversion and Management 2007;48:1536-43.

22] Stevanovic VD, Zivkovic B, Prica S, Maslovaric B, Karamarkovic V, Trkulja V. Prediction of thermal transients in district heating systems. Energy Conversion and Management 2009;50:2167-73.

23] Curti V, Von Spakovsky MR, Favrat D. An environomic approach for the modeling and optimization of a district heating network based on centralized and decentralized heat pumps, cogeneration and/or gas furnace. Part I: methodology. International Journal of Thermal Sciences 2000;39:721-30.

[24] Valdimarsson P. Pipe network diameter optimisation by graph theory. In: Ulanicki B, editor. Water Software Systems: theory and applications. Baldock: Research Studies Press; 2001. p. 1-13.

[25] Valdimarsson P. PipeLab 3.18 software. Nuon Technisch Bedrijf, University of Iceland; 2002

[26] Benonysson A, Bøhm B, Ravn HF. Operational optimization in a distric heating system. Energy Conversion and Management 1995;36:297-314.

[27] Bellache O, Bouyousfi B, Ait-Messaoudene N. Design and study of a geothermal district heating system at Hammam-Righa (Algeria). In: Sayigh AAM, editor. World renewable energy congress VI. Elsevier Science Ltd.; 2000. p. 305-9.

[28] Bloomquist RG. Geothermal district energy system analysis, design, and development. European summer school on geothermal energy applications. Romania: University of Oradea; 2001. p. 213-53.

[29] Yildirim N. District heating system of IZTECH Campus and its integration to the existing system. M.Sc. thesis, Izmir Institute of Technology; 2003, 158 p.

[30] Lund JW. Geothermal direct-use equipment overview. Klamath Falls, OR: Geo-HeatCenter Bulletin, Geo-HeatCenter; 1998.

[31] Togulga M. Processing and characterization of high performance piping materials for geothermal applications. M.Sc. thesis, Izmir Institute of Technology; 2003, 121 p.

[32] Ince U. A case study of material testing for corrosion in low temperature geothermal systems. M.Sc. thesis, Izmir Institute of Technology; 2005, 120 p.

[33] Kevin D, Rafferty PE. Piping. In: Lund JW, editor. Geothermal direct use engineering and design guidebook; 1998. p. 241-59.

34] TRANE Air Conditioning Inc. Personal communication, 2003, 2009.

[35] Teknoplas Inc. Personal communication, 2003, 2009.

[36] Kakac S, Liu H. Heat exchangers: selection, rating and thermal design. CRC Press; 1998. 